\title{
Viruses: a vast reservoir of genetic diversity and driver of global processes
}

\section{Curtis A Suttle}

Address: Departments of Earth \& Ocean Sciences, Microbiology \& Immunology, and Botany, University of British Columbia, Vancouver, British Columbia, Canada V6T 1 Z4

from Frontiers of Retrovirology: Complex retroviruses, retroelements and their hosts

Montpellier, France. 21-23 September 2009

Published: 24 September 2009

Retrovirology 2009, 6(Suppl 2):17 doi:10.1 186/1742-4690-6-S2-17

This abstract is available from: http://www.retrovirology.com/content/6/S2/l7

(c) 2009 Suttle; licensee BioMed Central Ltd.

Viruses are by far the most abundant "lifeforms" in the ocean; they exist wherever life is found. The estimated $10^{30}$ viruses in the ocean, if stretched end-to-end, would span farther than the nearest 60 galaxies. Every second there are about $10^{23}$ viral infections in the ocean. These infections are a major source of mortality; they influence the composition of marine communities, cause disease in organisms ranging from shrimp to whales, and drive biogeochemical cycles $[1,2]$. Each infection potentially introduces new genetic information into an organism, or into progeny viruses, and thereby drives the evolution of the host and viral assemblages. Our understanding of the impact of viruses on global systems continues to unfold, overthrowing the paradigm that viruses and viral-mediated processes are sidebars to global processes. My presentation will explore the current state of knowledge on the abundance and diversity of viruses in the sea, and the role that viruses play on nutrient and energy cycles. Genebased and metagenomic approaches have revealed enormous genetic richness in marine viral assemblages. For example, sequences of highly-conserved genes from environmental samples have shown vast genetic richness within related groups of viruses, and exposed the existence of many genetically distinct groups for which there are no cultured representatives.

\section{References}

I. Suttle CA: Viruses in the sea. Nature 2005, 437:356-361.

2. Suttle CA: Marine viruses - major players in the global ecosystem. Nature Reviews Microbiology 2007, 5:80I-8I2. 